\title{
Correction to: Gambling-related suicide in East African Community countries: evidence from press media reports
}

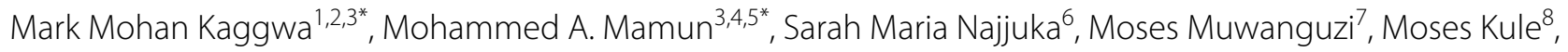
Rahel Nkola1,9, Alain Favina', Raymond Bernard Kihumuro7, Gideon Munaru'110, Innocent Arinaitwe7, Godfrey Zari Rukundo ${ }^{1,2}$ and Mark D. Griffiths ${ }^{11}$

\section{Correction to: BMC Public Health 22, 158 (2022)}

https://doi.org/10.1186/s12889-021-12306-2

Following publication of the original article [1], the authors would like to add an affiliation and correct the error in the author name of Mohammed A. Mamun.

The incorrect author name is: Mohammed A. Mamum

The correct author name is: Mohammed A. Mamun

The added affiliation is: Department of Public Health, Daffodil International University, Dhaka, Bangladesh.

The author group has been updated above and the original article [1] has been corrected.

\begin{abstract}
Author details
'Department of Psychiatry, Faculty of Medicine, Mbarara University of Science and Technology, Mbarara, Uganda. ${ }^{2}$ African Centre for Suicide Prevention and Research, Mbarara, Uganda. ${ }^{3}$ CHINTA Research Bangladesh, Savar, Dhaka 1342, Bangladesh. ${ }^{4}$ Department of Public Health and Informatics, Jahangirnagar University, Savar, Dhaka 1342, Bangladesh. ${ }^{5}$ Department of Public Health, Daffodil International University, Dhaka, Bangladesh. ${ }^{6}$ College of Health Sciences, Makerere University, Kampala, Uganda. ${ }^{7}$ Faculty of Medicine, Mbarara University of Science \& Technology, Mbarara, Uganda. ${ }^{8}$ Department of psychiatry, Mbarara Regional Referral Hospital, Mbarara, Uganda. ${ }^{9}$ Department of Psychiatry, Bugando Medical Center, Mwanza, Tanzania. ${ }^{10}$ Kisii Teaching and Referral Hospital, Kisii, Kenya. ${ }^{11}$ Psychology Department, Nottingham Trent University, 50 Shakespeare Street, Nottingham NG1 4FQ, UK.
\end{abstract}

Published online: 08 February 2022

\section{Reference}

1. Kaggwa, et al. Gambling-related suicide in East African Community countries: evidence from press media reports. BMC Public Health. 2022;22:158. https://doi.org/10.1186/s12889-021-12306-2.

The original article can be found online at https://doi.org/10.1186/s12889021-12306-2.

*Correspondence: kmarkmohan@gmail.com; mamunphi46@gmail.com

${ }^{3}$ CHINTA Research Bangladesh, Savar, Dhaka 1342, Bangladesh

${ }^{4}$ Department of Public Health and Informatics, Jahangirnagar University,

Savar, Dhaka 1342, Bangladesh

Full list of author information is available at the end of the article

(c) The Author(s) 2022. Open Access This article is licensed under a Creative Commons Attribution 4.0 International License, which permits use, sharing, adaptation, distribution and reproduction in any medium or format, as long as you give appropriate credit to the original author(s) and the source, provide a link to the Creative Commons licence, and indicate if changes were made. The images or other third party material in this article are included in the article's Creative Commons licence, unless indicated otherwise in a credit line to the material. If material is not included in the article's Creative Commons licence and your intended use is not permitted by statutory regulation or exceeds the permitted use, you will need to obtain permission directly from the copyright holder. To view a copy of this licence, visit http://creativecommons.org/licenses/by/4.0/. The Creative Commons Public Domain Dedication waiver (http://creativeco mmons.org/publicdomain/zero/1.0/) applies to the data made available in this article, unless otherwise stated in a credit line to the data. 